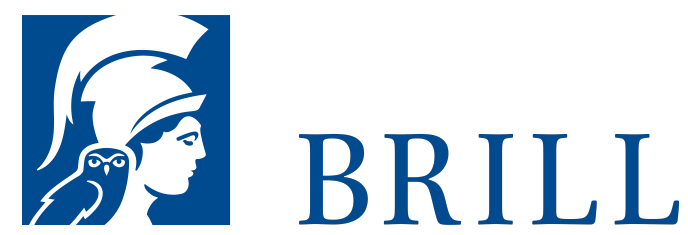

\title{
Das multiple Subjekt
}

Randgänge ästhetischer Subjektivität bei Fernando Pessoa, Samuel Beckett und Friederike Mayröcker

Author:Julia Weber

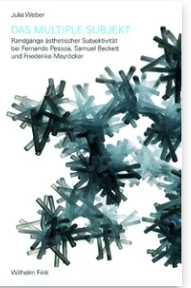

Die literarische Moderne ist ohne eine Vielzahl von Formen der Subjektentgrenzung kaum denkbar. Diese werden jedoch oft als Ausdruck tiefgreifender (Selbst-) Entfremdungsprozesse gewertet und selten in ihrer positiven Qualität als alternative Formen von Subjektivierung gewürdigt. Julia Weber deutet literarische Ich-Vervielfältigungen dagegen als schöpferische Auseinandersetzungen mit verlorenen Subjektgarantien. Gerade die Texte Fernando Pessoas, Samuel Becketts und Friederike Mayröckers reizen den mit der Ich-Vervielfältigung einhergehenden Kontrollverlust mit jeweils unterschiedlichen literarischen Strategien so weit aus, dass alternative Formen einer multiplen Subjektivität sichtbar werden.

Pages: 231

Seiten

Language:

German

Subjects:

General,

Literature and

Cultural Studies

Publisher: Brill |

Fink

Series:

Theorie und

Geschichte der

Literatur und der

Schönen Künste,

Volume: 117

E-Book (PDF)

Released online:

O2 Sep 2019

ISBN: 978-3-

8467-4889-3

List price

USD $\$ 52.00$

Paperback

Publication date:

21 Jul 2010

ISBN: 978-3-

7705-4889-7

List price

USD $\$ 52.00$ 
For more information see brill.com

Order information: Order online at brill.com +44330 333 0049 | customerservices@brill.com Submission information: brill.com/authors

Titles published by Brill | Fink, Brill | mentis or Brill | Schöningh: +49(o)715413279216| brill@brocom.de 